\title{
Immortalization of conditionally transformed chicken cells: loss of normal p53 expression is an early step that is independent of cell transformation
}

\author{
Eugen Ulrich, ${ }^{1}$ Guido Boehmelt, Adrian Bird, ${ }^{1}$ and Hartmut Beug \\ Research Institute for Molecular Pathology, 1030 Vienna, Austria
}

\begin{abstract}
Clones of mortal chicken fibroblasts and erythroblasts transformed by temperature-sensitive v-src and v-erb B oncoproteins have been developed into immortal cell lines that retain the conditional transformed phenotype. The expressions of two tumor suppressor genes, the retinoblastoma $(\mathbf{R b})$ gene and the p53 gene, were investigated during senescence, crisis, and cell line establishment. In temperature-sensitive (ts)-v-erb B erythroblasts and ts-v-src fibroblasts (as well as in v-myc macrophages), loss of p53 mRNA or expression of a mutated p53 gene invariably occurred in the early phase of immortalization. In contrast, expression of the $\mathbf{R b}$ gene was unchanged at all stages of immortalization. Inactivation of the original temperature-sensitive oncogene led to loss of the transformed phenotype in fibroblasts and to differentiation in erythroblasts, even in lines that were immortal and lacked $\mathrm{p} 53$. The results demonstrate that the process of immortalization is distinct from cell transformation, probably requiring different mutational events.
\end{abstract}

[Key Words: p53; immortalization of cultured cells; retinoblastoma; chicken cell lines; transformation]

Received November 4, 1991; revised version accepted February 17, 1992.

The outgrowth of immortal cells from cells of the body that normally have a finite lifespan is generally thought to be a critical step in tumorigenesis. An analogous process occurs when primary cells grown in culture give rise, after senescence and crisis, to permanent cell lines that are immortal. Recently, the so-called tumor suppressor genes or recessive oncogenes, retinoblastoma ( $\mathrm{Rb}$ ) and p53, have been directly implicated in both malignant transformation and transformation/immortalization of cells in culture, as the genes carry deletions, rearrangements, or point mutations in many tumors $(\mathrm{Ni}$ gro et al. 1989; Takahashi et al. 1989; Mulligan et al. 1990) and cell lines (Hinds et al. 1989). The role of tumor suppressors as negative regulators of cell proliferation is apparent when they are introduced into cells that lack the corresponding wild-type genes. Thus, transfection of a cloned $\mathrm{Rb}$ gene into retinoblastomas or osteosarcoma cells in which both copies of endogenous $\mathrm{Rb}$ had been inactivated caused loss of the transformed phenotype with respect to cell morphology, growth rate, soft agar colony formation, and tumorigenicity in nude mice (Huang et al. 1988). Likewise, expression of the wild-type p53 gene in human tumor cells and cell lines led to a reversible inhibition of proliferation by abolishing progression from $\mathrm{G}_{0} / \mathrm{G}_{1}$ into $\mathrm{S}$ phase (Diller et al. 1990;

'Present address: Institute of Cell and Molecular Biology, University of Edinburgh, Edinburgh EH9 3JR, UK.
Mercer et al. 1990). The view of these genes as negative growth regulators is strengthened further by the finding that several tumor viruses encode proteins that bind to $\mathrm{Rb}$ and p53 and apparently inactivate or promote their degradation (Lane and Crawford 1979; Linzer and Levine 1979; Scheffner et al. 19901.

Although the functions of $\mathrm{Rb}$ and $\mathrm{p} 53$ proteins are unknown, it has become clear that their behaviour is intimately linked to the cell cycle. Both proteins are posttranslationally modified in a cell cycle-dependent fashion. In the case of $\mathrm{Rb}$, interaction with viral oncogene products (e.g., SV40 large $\mathrm{T}$ and adenovirus E1A) and susceptibility to negative growth regulation by TGF- $\beta$ (in epithelial cells) seem to be dependent on these phosphorylation events (Buchkovich et al. 1989; Mihara et al. 1989; Laiho et al. 1990). The p53 protein is phosphorylated by the p34 cde2 kinase, and the protein accumulates during $G_{1}$ (Bischoff et al. 1990). Indirect evidence implicates p53 in controlling the onset of DNA replication during $\mathrm{S}$ phase. For example, the p53 protein colocalizes with viral DNA replication complexes in cells infected with herpesvirus (Wilcock and Lane 1991).

Cell cycle regulation of $\mathrm{p} 53$ and $\mathrm{Rb}$ fits well with their role as negative regulators of cell growth, suggesting that their normal function constitutes a hurdle that the normal cell must cross to progress through the cell cycle. If so, it follows that mutation of tumor suppressor genes, or of oncogenes that interact directly [SV40 large T, ad- 
enovirus E1A and E1B, human papillomavirus (HPV) E6 and E7] or indirectly (myc, fos, etc.) with tumor suppressor gene products, could remove the hurdle, thereby promoting unrestrained cell growth. In light of these ideas, we wished to ask whether loss or mutation of p53 is an essential step in the immortalization of cells in culture, and if so, whether immortalization was necessarily accompanied by a transformed phenotype. The chicken system offers several advantages in approaching these questions. First, the number of cell generations in culture before the cclls enter crisis approaches that of human primary cells $130-50$ gencrations in chickens as compared with 40-60 in humans) and is far greater than in mouse cells $(10-15$ generations; see Beug and Graf 1977 and references therein). As a result, mortal chicken cells can be cloned and grown in large numbers for analysis. Second, again like human cells, chicken cells are very difficult to immortalize. They remain in crisis for 2-6 months /compared with several weeks in the mouse), and outgrowth of immortal cells does not necessarily occur (Beug et al. 1982b). The advantage of the protracted immortalization period is that it allows us to obtain cells at the early (often unstable) stages of immortalization. Third, and most important, cells that have been transformed by mutant oncogenes encoding temperature-sensitive oncoproteins are available both as cloned mortal cell strains (from various cell lineages) and as immortal cell lines derived from the mortal clone. In these cells, oncoprotein function can be turned on and off at will by a simple shift between the permissive temperature $\left(37^{\circ} \mathrm{C}\right)$ and the nonpermissive temperature $\left(42^{\circ} \mathrm{C}\right)$. For example, a mortal clone of chick embryo fibroblasts transformed by a temperature-sensitive (ts)-vsrc mutant exhibits a fully transformed phenotype at $37^{\circ} \mathrm{C}$, whereas it is normal in every respect at $42^{\circ} \mathrm{C}$ (Beug et al. 1978). An immortal cell line derived from this clone retains the temperature-sensitive phenotype (see Results). Similarly, a mortal clone of chicken erythroblasts transformed by v-erbA/ts-v-erbB oncogenes grows as transformed crythroblasts at the permissive temperature but can be induced to synchronously differentiate into mature erythrocytes if oncoprotein function is inactivated (Beug et al. 1982a,b). As shown below, an immortalized cell line derived from this erythroblast clone can likewise be induced to terminally differentiate upon switching off both oncoproteins (Beug et al. 1982b). The combination of clonal mortal cells and their immortalized derivatives in which oncogenic transformation can be reversed at will provides a unique system for studying the immortalization process in isolation. An equivalent system has not been developed for human cells.

In this study we have used these and other chicken cell lines to study the expression of $\mathrm{Rb}$ and p53 mRNA at various stages in the immortalization process. We show that in five independent erythroblast cell lines, as well as fibroblast and macrophage lines, either expression of p53 mRNA was abolished or (more rarely) a mutated mRNA was expressed. In contrast, expression of the $\mathrm{Rb}$ gene was not affected. Loss or mutation of p53 expression was first detected in early, still unstable populations of immortal- ized cclls. The loss of p53 function during immortalization did not enhance or alter the transformed phenotype induced in erythroblasts and fibroblasts by their respective conditional oncoproteins. Thus, although the spontaneous immortalization of cells in culture is invariably accompanied by loss or mutation of $\mathrm{p} 53$, transformation by oncogenes is independent of the presence or absence of $\mathrm{p} 53$.

\section{Results}

Reversible transformation of mortal and immortalized fibroblast and erythroblast clones expressing temperature-sensitive oncogenes

Fibroblasts To obtain an immortalized line from clonal temperature-sensitive src-transformed fibroblasts, we chose a particularly well-growing clonal cell strain Fa (earlier referred to as TaSp7; Beug et al. 1978) that had been grown from an agar colony of ts- $\mathrm{v}-\operatorname{src}$ (strain Ta)infected chick embryo fibroblasts. This clone exhibited an in vitro lifespan of $>45$ generations in culture (Fig. lA). In the following text, such mortal clonal cell strains will be referred to simply as clones. When tested for its transformed phenotype at permissive $\left(37^{\circ} \mathrm{C}\right)$ and nonpermissive $\left(42^{\circ} \mathrm{C}\right)$ temperature, the Fa clone exhibited a normal morphology at $42^{\circ} \mathrm{C}$ [well-developed actin cables [stress fibers) and an extracellular fibronectin network] but showed a typical v-src-transformed morphology at $37^{\circ} \mathrm{C}$ (loss-of-actin filament bundles and reduced expression of an organized fibronectin network) (Fig. 2A). In addition, this clone had been shown to express a number of other fibroblast transformation parameters at $37^{\circ} \mathrm{C}$, but not at $42^{\circ} \mathrm{C}$ (Beug et al. 1978). When these cells were passaged at either $37^{\circ} \mathrm{C}$ or $42^{\circ} \mathrm{C}$, they slowed down in growth rate and displayed large, senescent cells after the same number of passages $\{\sim 45$ population doublings, Fig. 1A), still exhibiting a transformed or normal morphology, respectively (Fig. 2A, insets). After a crisis period of $\sim 3$ months, three foci of healthy, slow-growing cells were obtained at $42^{\circ} \mathrm{C}$. Only one of these foci could be propagated further, showing a gradually increasing growth rate during the next 1-2 months. After two subclonings of these cells, selecting for expression of a temperature-sensitive phenotype (Fig. 1A; see Materials and methods), the cloned line Fal was obtained. Two similar previous trials to grow out a cell line at $42^{\circ} \mathrm{C}$ and one trial at $37^{\circ} \mathrm{C}$ were unsuccessful, confirming that immortalization in chicken cells is an extremely rare event.

Further characterization of the Fal cell line revealed that like the mortal progenitor, its phenotype was normal at $42^{\circ} \mathrm{C}$ and transformed at $37^{\circ} \mathrm{C}$ /Fig. $2 \mathrm{~B}$ and data not shown). The interchange between normal and transformed phenotypes after temperature switch was also the same for the Fal line as for the pre-immortal clone (Fig. 2A, insets; Beug et al. 1978). Thus, immortalization did not significantly affect the v-src-induced transformed phenotype in these clonal fibroblasts, with the possible exception of colony formation in agar: The Fal cell line was somewhat abnormal in that colony formation was 
Figure 1. Time course (in months) of the establishment of the cell lines Fa-1 $\{A\rangle$ and $\mathrm{Ea} 1$ and $\mathrm{Ea} 2(B)$, and schematic representation of the mortal and immortalized fibroblast and erythroblast populations obtained during isolation of these lines. The status of p53 expression is indicated as follows: $1+1$ Normal-sized p53 message; | - | no p53 message; $1+*$ truncated p53 message; $(-* \mid$ p53 with inactivating point mutation; (?) not analyzed. The derivation of both fibroblast and erythoblast clones from semisolid medium and the approximate time points of cloning are indicated.

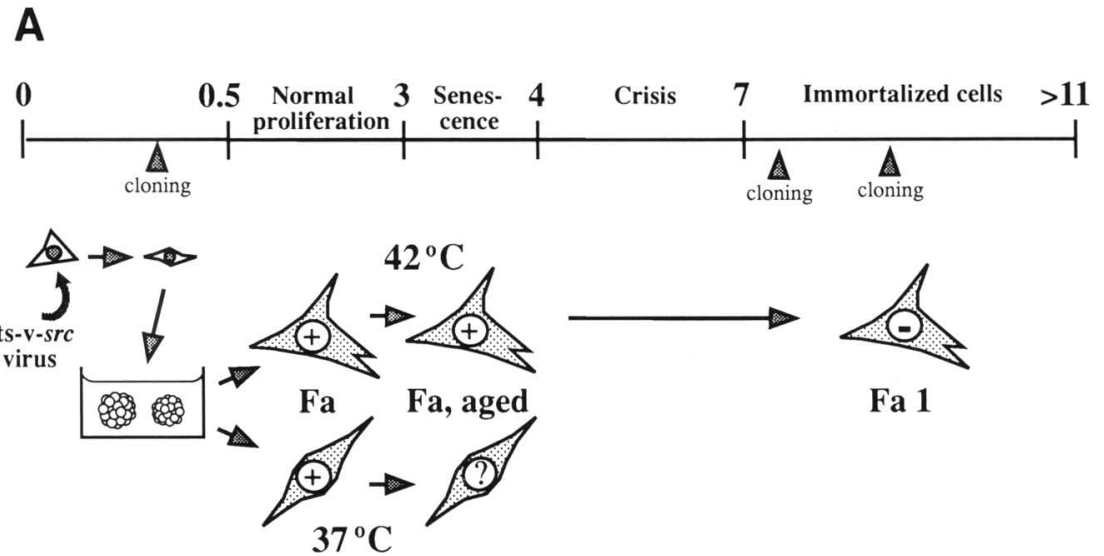

B

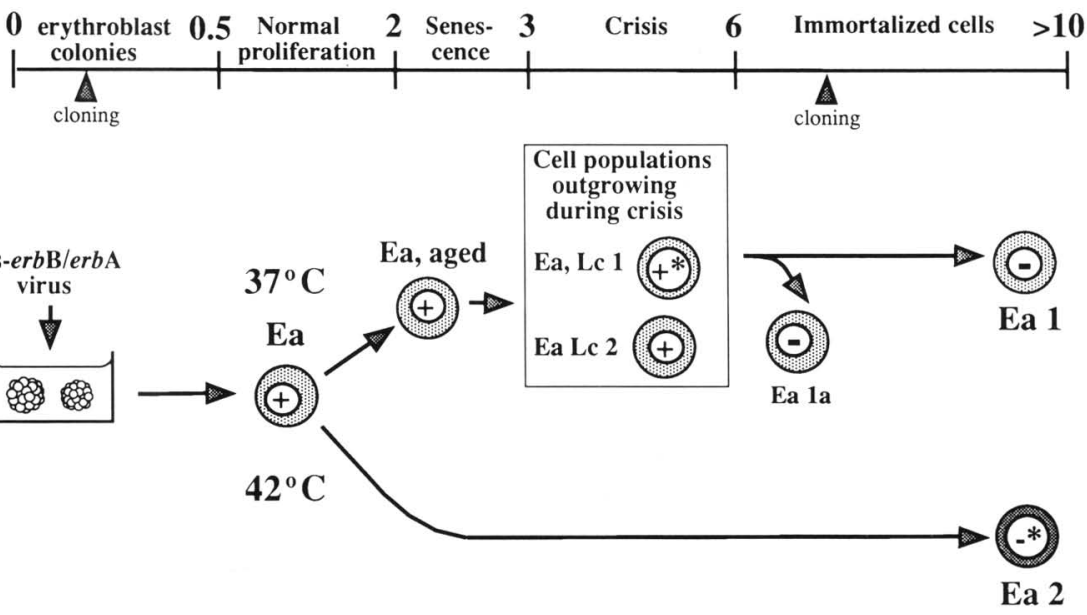

reduced rather than enhanced at the permissive temperature (data not shown).

Erythroblasts The Eal erythroblast cell line (elsewhere referred to as HD3! was isolated from an erythroblast clone (Ea) that had been nonproductively infected with a temperature-sensitive mutant (ts 34$)$ of the $t \mathrm{~s}-\mathrm{v}$ erbB/v-erbA-containing avian erythroblastosis virus (AEV) (Fig. 1B; see Beug et al. 1982b). Inactivation of the oncoproteins leads to reversal of transformation and complete differentiation into mature erythroblasts (Beug et al. 1982a). To compare the mortal clone Ea and the immortalized line Eal in this respect, the two cell types were cultivated in $\mathrm{pH} 8$ differentiation medium at $42^{\circ} \mathrm{C}$ (to inactivate ts-v-erbB oncoprotein function) and in the presence of the protein kinase inhibitor $\mathrm{H}$ 7 (to suppress $\mathrm{v}$-erbA protein function by preventing its phosphorylation; Glineur et al. 1990). Both the mortal clone Ea and the immortalized line Eal completely differentiated into mature erythrocytes within $4-5$ days at $42^{\circ} \mathrm{C}$ (Fig. 3). This again demonstrates that immortalization per se had no detectable effect on the expression of the transformed erythroblast phenotype induced by $\mathrm{v}-e r b \mathrm{~B}$ and $\mathrm{v}$-erbA oncogenes.
Expression of $p 53$ and $R b m R N A$ in mortal vs. immortalized fibroblast and erythroblast clones

Cells from the Fa fibroblast clone ( 25 population doublings) and from the Fal line (passage 53 after second subcloning; see Materials and methods) were grown for 2 days at $37^{\circ} \mathrm{C}$ and $42^{\circ} \mathrm{C}$, respectively and analyzed for p53, $\mathrm{Rb}$ and, as a control, $\beta$-actin expression, using Northern blots of total and poly $\mid \mathrm{A})^{+}$RNA. In addition, Fa cells were passaged at $42^{\circ} \mathrm{C}$ until they essentially stopped growing and displayed senescent cells (Fig. 2A, insets) before preparing RNA (Fa aged). Figure 4A shows that the cell strain $\mathrm{Fa}$ expresses both p53 and $\mathrm{Rb}$ message, whereas no p53 mRNA was detectable in the Fal line. The Fal line did, however, express normal levels of $\mathrm{Rb}$ and $\beta$-actin mRNA. This pattern was seen in normal and transformed cells grown at both growth temperatures. The absence of p53 mRNA in Fal cells was verified by analyzing poly $(\mathrm{A})^{+}$RNA (data not shown). On the other hand, two different, independently derived populations of senescent, essentially stationary $\mathrm{Fa}$ cells still expressed p53 mRNA at normal levels (Fig. 4B), suggesting that the events leading to loss of p53 expression are not a consequence of senescence. 
A

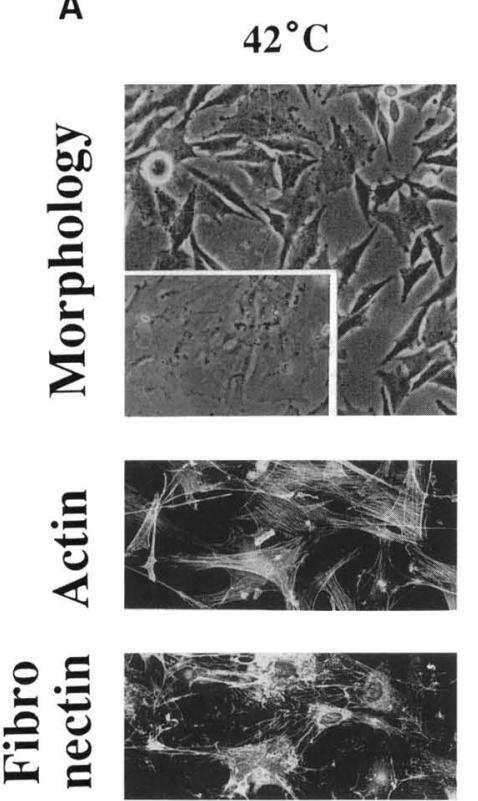

$37^{\circ} \mathrm{C}$
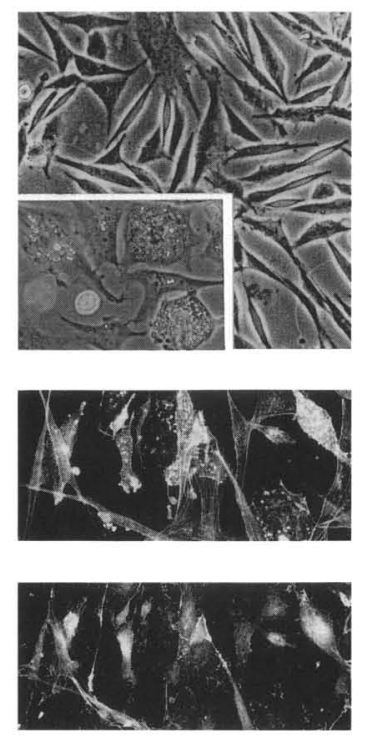

B
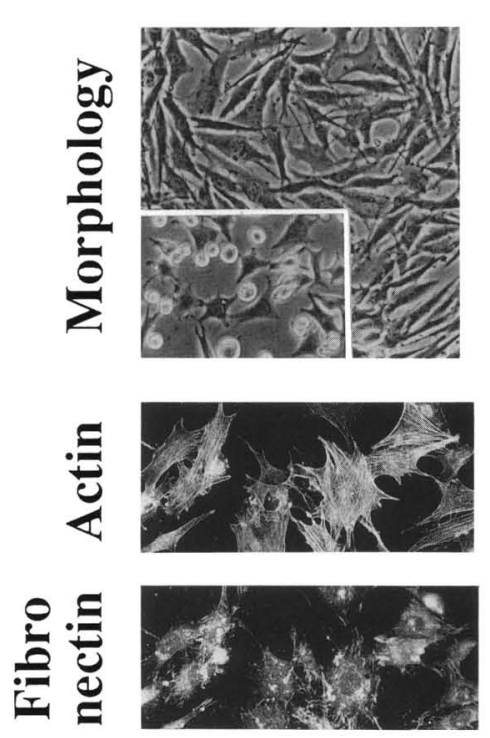

$37^{\circ} \mathrm{C}$
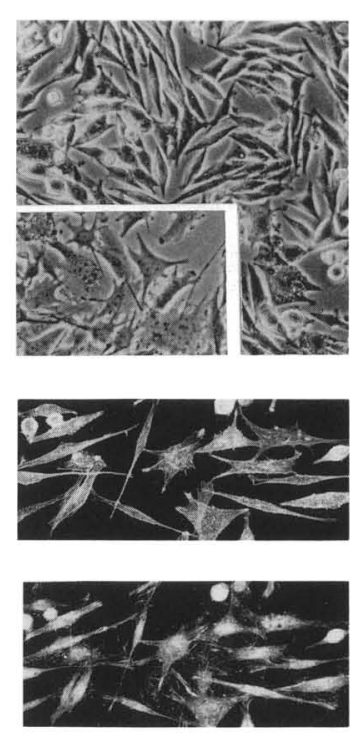

Figure 2. Reversible transformation of a mortal fibroblast clone $\mathrm{Fa}(A)$ and a derivative immortal cell line Fal $(B)$ as assayed by cell morphology, expression of actin cables, and cxpression of fibronectin at the permissive and nonpermissive temperature. (A) Phase micrographs of clone Fa grown at $42^{\circ} \mathrm{C}$ (mostly flat morphology) and $37^{\circ} \mathrm{C}$ (spindle-like transformed morphology) are shown in the upper panels. (Insets) Stationary, aged cells passaged at the respective temperature until senescence. The aged cells still display a (somewhat aberrant) normal $\left(42^{\circ} \mathrm{C}\right)$ and transformed $\left(37^{\circ} \mathrm{C}\right)$ morphology. The middle and lower panels show photographs of the same fields of cells stained with TRITC-phalloidin (actin) and anti-fibronectin antibody followed by FITC-labeled second antibody (fibronectin) and photographed using filter combinations to view FITC and TRITC fluorescence, respectively (Beug et al. 1978). Note abundant actin cables and fibronectin network at $42^{\circ} \mathrm{C}$ but not at $37^{\circ} \mathrm{C} .(B)$ Cells from the Fal cell line were photographed at $42^{\circ} \mathrm{C}$ and $37^{\circ} \mathrm{C}$ as in $A$. (Insets) Cells shifted from $42^{\circ} \mathrm{C}$ to $37^{\circ} \mathrm{C}$ (left) or from $37^{\circ} \mathrm{C}$ to $42^{\circ} \mathrm{C}$ (right), indicating that the cell line had retained the ability of the Fa clone to transform rapidly or normalize upon temperature shift. Note similar loss of actin cables and flbronectin network upon shift to $37^{\circ} \mathrm{C}$ as seen for the Fa clone.

Very similar results were obtained in erythroblasts (Fig. 1B). Cells of the mortal strain Ea expressed p53 and $\mathrm{Rb} \mathrm{RNA}$, both as transformed erythroblasts at $37^{\circ} \mathrm{C}$ and as partially mature reticulocytes after 2 days at $42^{\circ} \mathrm{C}$. In contrast, equivalent cell preparations from line Eal contained no detectable levels of p53 mRNA but contained normal levels of Rb message (Fig. 5A). Again, senescent Ea cells (characterized by very slow growth, large irregular cells, and accumulating dead cells) still expressed p53 mRNA (Fig. 5A, Ea aged).

Loss or mutation of p53 is correlated with immortalization of erythroblasts

In contrast to the fibroblast system, where only one cell line was obtained, two further immortal erythoblast cell lines were available for which the parent clonal cell strain could be analyzed (Ea2 and $\mathrm{Eb} 1$, earlier referred to as HD2 and HD4, respectively; Beug et al. 1982b). In addition, one further erythroblast line, for which no parent clone was available, was tested (Ec1; earlier, HD1). Finally, three separate mortal erythroblast clones that were generated at the same time as Ea and Eb, but had not been developed into cell lines, were included in the analysis. All tested clones expressed p 53 mRNA of ap- parently normal size at normal levels (Fig. 5; Table 1). In contrast, the immortal line Ebl exhibited undetectable levels of p53 mRNA (verified by the use of poly $\mid \mathrm{A})^{+}$ RNA; Table 1 and data not shown). The two immortal lines Ea2 and Ecl, however, did express p53 mRNA. The Ecl line expressed abnormally high levels of a heavily truncated p53 RNA, as suggested by its reduced size (1 $\mathrm{kb}$ instead of $1.5 \mathrm{~kb}$; Fig. $5 \mathrm{~B})$. The Ea2 line, on the other hand, expressed an apparently normal-sized p53 mRNA at levels similar to those in the Ea clone (Fig. 5B). Interestingly, the Ea2 line was derived from the same erythroblast clone $(\mathrm{Ea})$ as $\mathrm{Eal}$ but was independently established by cultivation at $42^{\circ} \mathrm{C}$ (Fig. 1B) and, thus, by selection for cells that would grow rather than differentiate at the nonpermissive temperature.

\section{Expression of a mutated p53 gene in line Ea2}

To check whether expression of a normal-sized p53 mRNA by line Ea2 represents an exception to the apparent correlation between immortalization and loss or mutation of p53, we isolated parts of the p53 gene from both $\mathrm{Ea}$ and $\mathrm{Ea} 2$ by polymerase chain reaction (PCR) amplification of cDNA prepared from the respective RNAs and obtained DNA sequence (Fig. 6). A 586-bp fragment (en- 
Ulrich et al.

\section{clone Ea}

Figure 3. Comparison of transformed phenotype at $37^{\circ} \mathrm{C}$ and differentiation at $42^{\circ} \mathrm{C}$ of erythroblast clone $\mathrm{Ea}$ and its derivative cell line Eal. Cells were shifted to $42^{\circ} \mathrm{C}$ for 4 days $(\mathrm{Ea})$ and 5 days $\{$ Eal $\}$ or kept at $37^{\circ} \mathrm{C}$ as described in Materials and methods. Photographs of cytospin preparations stained with neutal benzidine plus histological dyes and viewed under blue light lleft parts of upper and lower panelsi to reveal hemoglobin staining (see Materials and methods) or under green light (right parts of upper panels| to reveal histological details of the immature cells at $37^{\circ} \mathrm{C}$ are shown. Note similar appearance of both immature and mature cells from clone Ea and line Eal.

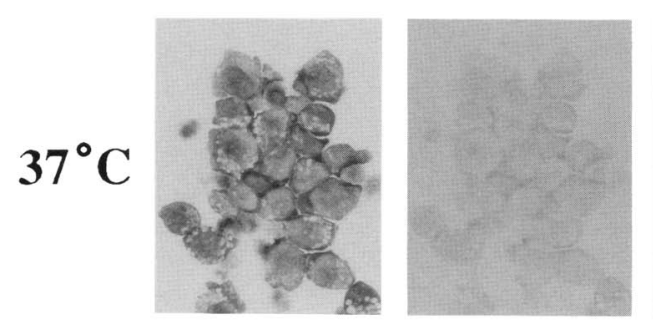

cell line Ea1

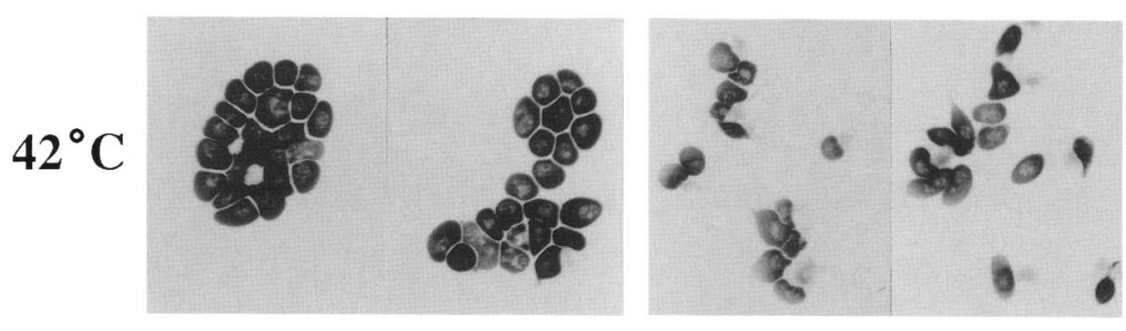

compassing codons 90-286 of a total of 367! showed a single-base alteration from TGC at codon 224 in strain $\mathrm{Ea}$ to TCC at the same position in Ea2. This result was obtained in two independent experiments, thus ruling out a PCR artifact. The affected triplet encodes cysteine in the Ea cDNA and serine in the Ea2 cDNA. Comparison with the deduced amino acid sequences of mouse, human, Xenopus, and chicken p53 proteins showed that amino acid 224 is in a highly conserved region (region IV; Soussi et al. 1990! and is invariably cysteine. Sequencing of the three other highly conserved regions, II, III, and V, failed to show any other mutation |region I of Soussi et al. (1990) is not highly conserved in the chicken sequence]. We conclude that the immortal Ea2 line expresses p53 mRNA carrying a mutation in a highly conserved region of the protein, suggesting that this protein is either nonfunctional or altered in its function isee Discussion|. The parental, mortal clone Ea does not carry this mutation. Attempts to detect trace amounts of the unmutated p53 RNA by sequencing pooled PCR products from Ea2 cells were unsuccessful, suggesting that the normal allele, if present, is inactive.

\section{Loss or mutation of $p 53$ is an early step in the immortalization process}

During establishment of the Eal cell line, aliquots of cells had been frozen at different stages: senescence; outgrowth of labile cell populations during crisis; and carly phases of cell line establishment. As shown in Figure 1B, clone Ea cultivated at $37^{\circ} \mathrm{C}$ underwent senescence after $\sim 40$ divisions, resulting in a drastic decrease in growth rate, the appearance of irregularly sized, large cells, and cell disintegration. At this stage (Fig. 1B), cells still expressed a normal-sized p53 mRNA (Fig. 5A; Ea aged). After 2 months of crisis, a very small proportion of the cells started outgrowing as clumps of healthy, small erythroblasts. Because these cell populations did not tol- erate cloning and were lost easily during operations to purify them from dead cells (which constituted the majority of these cell populations), they were cultivated in several parallel dishes and aliquots were frozen down when sufficient cell numbers were reached. RNA samples prepared from two such line candidates (Lcs) that were frozen down within a month were probed for $\mathrm{p} 53$ expression (Fig. 1B, EaLcl and EaLc2). As shown in Figure $5 \mathrm{C}$, a truncated p53 mRNA was present in EaLcl cells, whereas an apparently normal-sized p53 RNA was still present in EaLc2.

One month later, we had the first indications that a stable immortalized cell line was growing out. Part of that cell population (referred to as Eala) had been successfully infected with helper virus to prove its nonproducer nature (Graf 1973 and data not shown). These Eala cells represent an early stage of immortalization, as they were frozen 1 month before the Eal cell line was successfully cloned (see Fig. 1B). Northern blot analysis showed that Eala cells no longer expressed p53 mRNA (Fig. 5B). Early passages of the cloned immortal Eal cell line that were frozen in 1979, as well as samples that have been passaged for $>100$ generations in our laboratory invariably lacked p53 RNA but expressed Rb RNA at apparently normal levels (Fig. 5A and data not shown). Thus, the loss of p53 expression must have occurred somewhere during the crisis/early immortalization period.

Very similar results, although documented by fewer cell samples, were obtained during immortalization of the wild-type AEV-transformed erythroblast clone Eb. Whereas cells from the Eb clone still grew for $>10$ population doublings after thawing and expressed normalsized p53 message, cells frozen during early stages of immortalization (EbLc1) already lacked p53 mRNA (Table 1 ).

Finally, our notion that loss and/or mutation of the p53 gene is an event early in cell line establishment was 


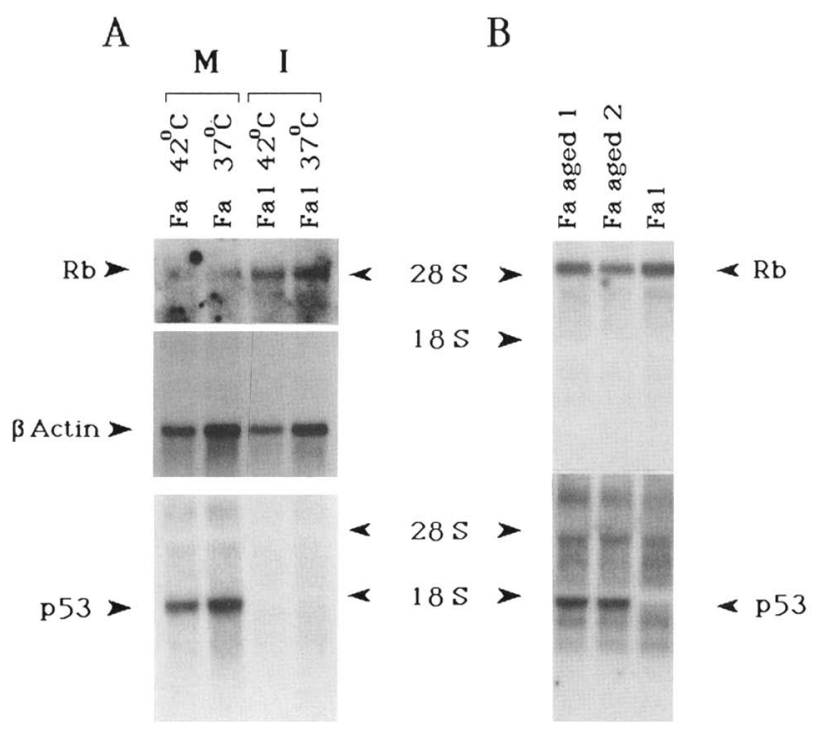

Figure 4. Loss of p53 mRNA during immortalization of fibroblast clone Fa. $|A|$ RNA was prepared from mortal (M) Fa cells and from immortal (I) Fal cells growing at $37^{\circ} \mathrm{C}$ (transformed phenotype) or $42^{\circ} \mathrm{C}$ (nontransformed phenotype; see Fig. 2). A single Northern blot of total RNA was probed sequentially with part of the chicken Rb gene cDNA, the chicken $\beta$-actin cDNA, and the p53 cDNA, as described in Materials and methods. The sizes of the appropriate bands for each probe are indicated by labeled arrowheads. The large $\mathrm{Rb}$ band is smeared downward in this preparation owing to degradation that affects this $4.6-\mathrm{kb}$ RNA more than the smaller actin $(2-\mathrm{kb})$ and p53 $(1.5-\mathrm{kb})$ mRNAs. The presence of normal levels of full-length Rb RNA in the Fal line is corroborated in $B .(B)$ RNA from two samples of senescent Fa cells (Fa aged; see Fig. IA) compared with Fal RNA after probing with $\mathrm{Rb}$ or 553 probes. corroborated by analyzing cell samples frozen during the immortalizaton of line Ec1. Growing cells of the mortal clone Ec were not available, but cell populations frozen early during immortalization (EcLcl from November 1977 and EcLc2 from January 1978) already expressed a heavily truncated p53 message, as did the immortal Ecl cell line analyzed from cells frozen 10 years later ( $\mathrm{Ta}$ ble 1).

Unfortunately, we were unable to obtain a continuously growing cell population from any of the above line candidates (EaLc1, EaLc2, EbLc1, EcLcl, EcLc2). A trivial explanation for this is that these slow-growing, highly unstable cell populations did not tolerate freezing and thawing, particularly because they had been stored in liquid nitrogen for $>14$ years. Because we had no problems growing the established lines Ea1, Ea2, Eb, and Ec, which had been frozen for a similarly long time, it is possible that loss of 553 represents an early step in immortalization of chicken erythroblasts that is necessary, but perhaps not sufficient, for full immortalization. Evidence for the notion that immortalization is a multistep process has recently been obtained in other systems (Wright et al. 1989; Strauss et al. 1990).

\section{Loss of p53 expression during immortalization of $v$-myc-transformed macrophages}

Immortalization is thought to be induced or accelerated by nuclear oncogenes (e.g., myc, fos, adenovirus ElA, SV40 large $\mathrm{T}$ ) but not by cytoplasmic ones (e.g., the src and erbB oncogenes used here). We therefore tested whether and how easily immortal cell lines could be isolated from avian fibroblasts and macrophage clones
A

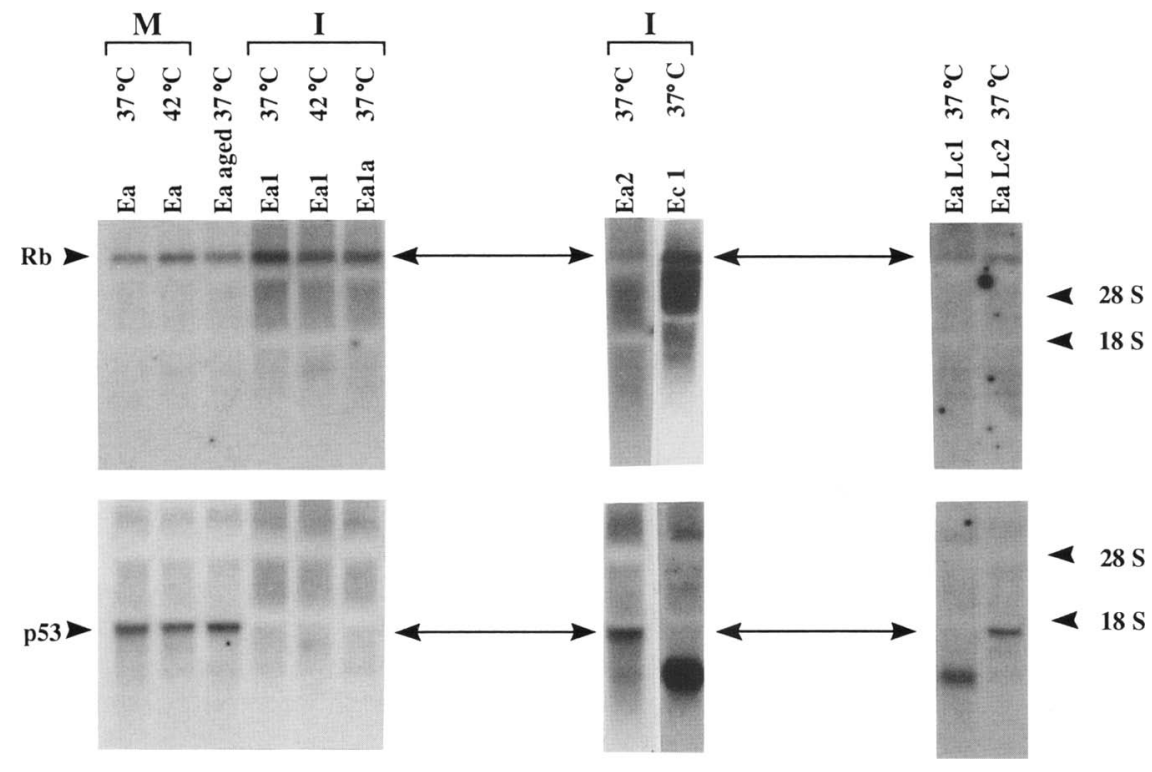

Figure 5. Changes in p53 mRNA during immortalization of erythroblast cells. $|A|$ RNA was prepared from mortal (M) Ea cells and immortal (I) Eal cells grown at $37^{\circ} \mathrm{C}$ or $42^{\circ} \mathrm{C}$, and also from senescent Ea cells (Ea aged) at $37^{\circ} \mathrm{C}$. Northern blots were probed as described in Materials and methods. $(B)$ Immortal erythroblast lines $\mathrm{Ea} 2$ and $\mathrm{Ec} 1$ (see text) show, respectively, a normal-sized p53 mRNA and a truncated p53 mRNA in the Northern blot assay. $|C|$ EaLcl and EaLc2, representing early outgrowths of senescent Ea cells, show, respectively, a truncated p $53 \mathrm{mRNA}$ and an apparently normal p53 mRNA. 
Ulrich et al.

Table 1. Expression of p53 and $R b \mathrm{mRNA}$ in chicken cells during immortalization

\begin{tabular}{lcc}
\hline $\begin{array}{l}\text { Erythroblast } \\
\text { strain or line }\end{array}$ & p53 & $\mathrm{Rb}$ \\
\hline Clone Eb & + & + \\
Clone Ed & + & + \\
Clone Ee & + & + \\
Clone Ef & + & + \\
EbLc1 & - & + \\
Ebl & - & + \\
EcLc1 & $+^{a}$ & + \\
EcLc2 & $+^{\mathrm{a}}$ & + \\
\hline
\end{tabular}

Expression of mRNAs excluding data presented in Fig. 5 and summarized in Fig. 1B.

${ }^{\mathrm{a}} \mathrm{A}$ truncated p53 mRNA of $\sim 1 \mathrm{~kb}$ was detected.

transformed by the v-myc-expressing MC29 virus iGraf 1973|. V-myc-transformed cells from a normal chicken fibroblast clone that exhibited an in vitro lifespan of $>45$ generations in culture (clone 1/77; Beug and Graf 1977) could not be developed into a cell line, although the senescent cells were kept in culture for $>3$ months. In contrast, using a pool of $\mathrm{v}$-myc oncogene-transformed macrophage clones, a continuous macrophage cell line Mal (earlier referred to as HD11; Beug et al. 1982b; Leutz et al. 1984) could be grown after a senescence period of 1 month and a prolonged crisis period $(2$ monthsi, suggesting that $\mathrm{v}$-myc-transformed cells in the chicken are not easier to immortalize than cells transformed by cytoplasmic oncogenes. Although the mortal macrophages $|\mathrm{Ma}|$ expressed normal levels of p53, the immortal cell line Mal failed to do so (Fig. 7). This result could be verified by analysis of poly $(A)^{-}$RNA (data not shown). As expected, Mal cells frozen down shortly after immortalization also failed to express p53 mRNA (not shown). These results confirm our notion that loss (or mutation) of p53 is a consistent feature of the immortalization process in chicken cells, regardless of the transtorming oncogene or the cell lineage of origin.

\section{Discussion}

Loss of wild-type p53 is a necessary early event in immortalization of chicken cells

Our results strongly suggest that in cultured chicken cells the expression of wild-type p53 is incompatible with cell immortality. Previous comparisons between cells at the end of the immortalization process and primary cells have noted frequent alterations of p53 gene expression in the immortal lines (e.g., Friend erythroleukemia cell lines; Munroe et al. 1990). By following the progression to immortality of individual primary cell clones, we implicate the loss of normal p53 as a pivotal event in the immortalization process. Cloned transformed primary cells of fibroblast, erythroblast, and macrophage origin all expressed apparently normal p 53 mRNA through the stages of normal proliferation and $3^{\prime}$

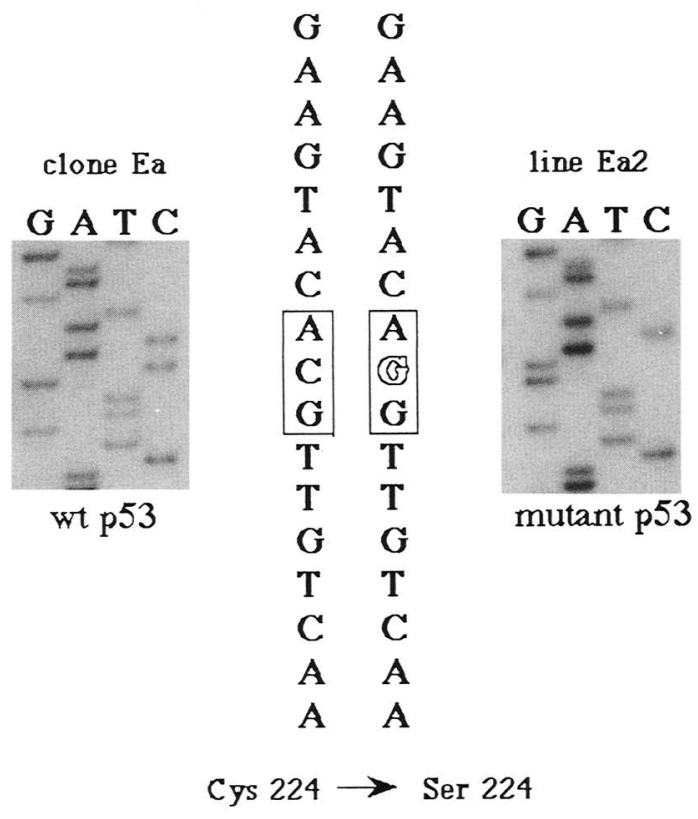

Figure 6. A point mutation in a conserved region of the p53 protein has occurred in the immortal erythroblast line Ea2. A segment of the p53 mRNA was amplified directly from RNA of the parental clone Ea and its derivative immortal line Ea2, using the primers described in Materials and methods. Portions of the autoradiographs that were used to determine the sequence of the amplified segments in Ea and Ea2 are shown, together with the sequence surrounding codon 224 (boxed).

senescence. On the other hand, spontaneously immortalized cells that eventually arose from the primary cells in crisis all exhibited loss or alteration of p53 mRNA. The transition from crisis to immortality was investigated by analyzing four early (uncloned) outgrowing cell populations from three independent erythroblast cultures. One of these line candidates did not express p53 mRNA, and the other two showed a heavily truncated message. The results indicate that loss or mutation of normal p53 expression is a very early event in the evolution of immortal cell lines and may therefore be a critical step in the transition to immortality. Our results do not prove that the observed changes in $\mathrm{p} 53$ are sufficient in themselves to cause immortalization. To address this point, we are currently introducing the mutated p53 genes of Ea2 and Ecl into transformed erythroblast clones by retroviral vectors.

The p53 gene product may have a dual function in oncogenesis (Levine et al. 1991). On one hand, wild-type p53 functions as a tumor suppressor gene, acting as a negative regulator of cell proliferation. Thus, uncontrolled growth might ensue if p53 expression is abolished by deletion of the gene or inactivation of the protein. On the other hand, certain mutations in $\mathrm{p} 53$ seem to convert it into a dominant oncogene, leading to cell transformation in cooperation with cytoplasmic oncogenes (Eliyahu 


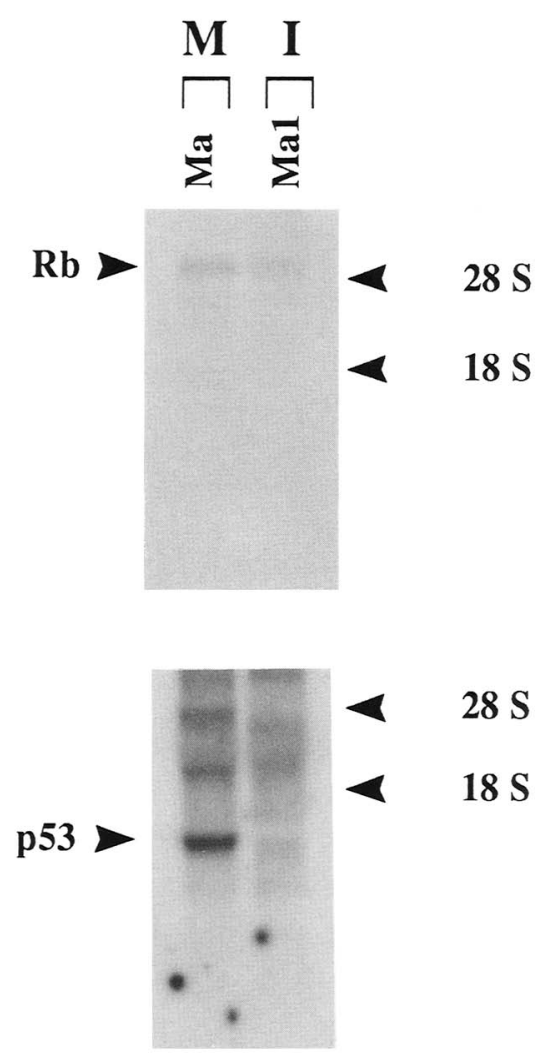

Figure 7. Loss of p53 expression during progression from the macrophage cell clone Ma to the immortal cell line Mal. Northern blots of RNA from each cell type were probed with $\mathrm{Rb}$ and p53 probes as described in Materials and methods.

et al. 1984; Hinds et al. 1989) and promoting immortalization of rodent flbroblasts (Jenkins et al. 1984; Rovinski and Benchimol 1988). Whereas a mutated, dominantly acting p 53 gene is the most common alteration in mammalian cell lines and tumors (Levine et al. 1991), complete loss of p53 expression was observed most often in chicken cells. The reason for this difference may be that the chicken cells that we used already expressed an externally introduced transforming oncogene $(e r b \mathrm{~B}$ in erythroblasts, or v-myc in macrophages). In the presence of the transforming oncogene, simple loss of $\mathrm{p} 53$ expression might be sufficient for immortalization. Compatible with this hypothesis is the finding that one of the few erythroblast cell lines expressing a mutated p53 (line Ea2) was selected under conditions where the transforming oncogene was inactive (i.e., at the nonpermissive temperature). Thus, the Ea2 line probably emerged under a strong selective pressure not only to lose normal p53 but also to acquire a transforming oncogene (to replace the inactivated ts-v-erbB). A testable prediction is that the mutation at position 224 of the p53 gene contributes to both of these requirements. The same reasoning may explain the puzzling fact that line Eal (which was selected for its ability to differentiate at $42^{\circ} \mathrm{C}$, i.e., for the absence of an oncogene other than ts-v-erbB) had lost p53, whereas a cell preparation frozen early during estab- lishment of this line contained a truncated p53 (Figs. 1B and 5 C). It is likely that immortalized cells originating from such cells were discarded upon cloning of the Eal line, because they failed to differentiate.

It should be noted that no such selective pressure should be operative in fibroblasts, which proliferate similarly in the presence or absence of a transforming $\mathrm{v}$-src oncoprotein. This may explain why the p53 gene was deleted rather than mutated in the Fal cell line, which was also selected at $42^{\circ} \mathrm{C}$, because the pre-immortal $\mathrm{Fa}$ cells exhibited a high growth rate and a long in vitro lifespan regardless of the presence or absence of a functional v-src oncoprotein (H. Beug and T. Graf, unpubl.; see Beug and Graf 1977). It is possible that the particularly long lifespan of the TaSp7 clone was the result of activation of an oncogene in the mortal ancestors of $\mathrm{Fal}$ prior to selection.

What is the mechanism of p53 mRNA loss during immortalization of our chicken cell lines? The simplest possibility is that a genetic alteration has rendered the gene nonfunctional, for example, by complete or partial deletion. Preliminary studies of the truncated mRNA in line Ecl (Fig. 5) indicate that sequences encoding the amino-terminal half of the p53 protein are missing in this transcript. Whether this is the result of deletion in the gene or a mutation affecting splicing is not yet known. Most intriguing, however, are the majority of cell lines that lack p53 mRNA altogether. Preliminary examination of the p53 gene in the nonexpressing erythroid line Ea1 by Southern blots showed no evidence of gross rearrangement of the gene, although small deletions or point mutations would not have been detected (E. Ulrich, unpubl.). Another possibility is that the mechanism of gene inactivation is epigenetic. It is known that a variety of genes in cultured cells are inactivated by DNA methylation at $\mathrm{CpG}$ islands, which are normally constitutively methylation free (Antequera et al. 1990; Jones et al. 1990). Recently, it has been found that the CpG island at the Rb gene is sometimes methylated in retinoblastomas (Greger et al. 1989; Sakai et al. 1991). Southern blot analysis (E. Ulrich, unpubl.) shows that p53 sequences are nonmethylated in both mortal Ea cells and immortal Eal cells, making it less likely, though not impossible, that DNA methylation is involved.

Is loss of p53 a necessary step in immortalization? Although no exceptions have been found in our chicken cell lines from fibroblastic, erythroid, and myeloid lineages, the situation seems to be more complicated in avian lymphoid cells transformed by the v-rel oncogene, a mutated transcription factor related to NF-kB /Ghosh et al. 1990). Initially these cells were thought to represent instantaneously immortalized, very immature, preB/pre-T-like cells (Lewis et al. 1981). Recently, however, these cells were shown to frequently undergo senescence after a greatly prolonged in vitro lifespan of $60-80$ population doublings when passaged as rather small cell populations (Morrison et al. 1991). When passaged as larger cell populations, some clones could be passaged to $>150$ doublings. In preliminary experiments, all of these 
rel-transformed clones expressed an apparent unchanged p53 (E. Ulrich and G. Boehmelt, unpubl.). It is therefore tempting to speculate that v-rel replaces or cooperates with a recessive oncogene, leading to cellular changes such as the loss of $\mathrm{p} 53$.

\section{Is immortalization a necessary step in oncogenesis?}

The results presented here favor the view that immortalizaton and malignant transformation are separate, but interdependent, sets of mutational events. First, the fibroblast and erythroblast clones described were reversibly transformed at the outset (owing to the temperature sensitivity of the original oncogenes! but were nevertheless mortal. This was also true in vivo, because wild-type AEV was found to induce mortal erythrolcukemia cclls in chicks (Graf et al. 1977). Second, transformation could still be reversed after immortalization had occurred. At the nonpermissive temperature, erythroblasts differentiated to give erythrocytes, whereas fibroblasts reverted to a typical fibroblast morphology. By this and several other criteria, the behavior of these cell lines before $\langle\mathrm{Ea}$ and $\mathrm{Fa}$ | and after $\{\mathrm{Ea}$ l and Fal $\}$ immortalization was similar or even identical (see Figs. 2 and 3). It is therefore tempting to see the escape from crisis, due at least in part to the loss of normal p53, as an event principally independent of transformation.

Are immortalization and transformation independent events in tumorigenesis? Attempts to answer this question must take into account that the frequency of immortalization of a given cell type varies widely in different animal species and is inversely correlated to the in vitro lifespan of primary cells. Thus, immortalization seems to be relatively frequent in mice and rats as well as certain birds (Japanese quail), whose primary cells exhibit short in vitro lifespans $(10-20$ generations $\mid$. On the other hand, primate (including human) cells and chicken cells exhibit much longer lifespans and are difficult or even impossible to immortalize (Hayflick 1965; Macieira-Coelho 1976, 1980). For these findings to be relevant in vivo, it is necessary that immortalization be a common event during tumorigenesis in mice but a rare event in chickens and humans. This is exactly what is found. Most tumors isolated from mice, including leukemias, consist of cells that are already immortalized. Oncogene-transformed mouse or rat fibroblasts that are mortal have usually been found to become immortalized when they are recovered from a tumor $[\mathrm{H}$. Land, pers. comm.). In contrast, we have been unable to detect immortalized cells in tumors and leukemias induced in chickens by various oncogene-containing retroviruses. Rather, these cells underwent senescence in culturc after in vitro lifespans that were typical for chicken cells. Furthermore, the isolation of cell lines from the cultured tumor cells was as difficult as from in vitro-transformed cells and involved a clearly defined crisis period (Metz and Graf 1991; H. Beug and T. Graf, unpubl.). In humans, the situation is complicated by the fact that primary cells derived from most human tumors (e.g., carcinomas) are very reluctant to grow in culture, rendering it diffi- cult to decide whether the cells that eventually grow out had to undergo a crisis before doing so. In spite of this limitation, a variety of human myeloid and lymphoid leukemias have been isolated from patients and shown to consist of nonimmortalized cells that undergo a typical crisis period before progressing (in some cases) to immortalized lines ( $H$. Messner, pers. comm.). Therefore, we propose that in contrast to the prevailing dogma, immortalization is not a prerequisite for tumorigenesis but, rather, a separate set of mutational events (Wright et al. 1989; Strauss et al. 1990) that may or may not contribute to transformation. Our hypothesis does not question the established fact that the frequency of mutational events involved in immortalization is enhanced by a multitude of transforming oncogenes. Nor does it conflict with the assumption that the mutational events necessary (but not sufficient) for full immortalization represent important steps in tumorigenesis. One such step certainly could be the loss or mutation of p53, occurring in human tumors of many different kinds. Our result that $\mathrm{v}$-rel transformation of chicken fibroblasts and lymphoid cells leads to a two- to threefold increase of in vitro lifespan without causing instantaneous immortalization may help to identify other events that contribute to immortalization.

\section{Materials and methods}

Cells and cell culture

The origins of the fibroblast clone TaSp7 /transformed with the Ta temperature-sensitive mutant of the Bryan high-titer strain of Rous sarcoma virus) has been described earlier (Beug et al. 1978). The erythroblast clones Ea (ts34A6), Eb (9D4), Ed (ts34NPB4), Ee (ts151 AEVcl3), and Ef (ts186AEVcl5| were isolated according to standard procedures (Graf et al. 1978) between 1978 and 1980. The isolation of the cell lines Eal (HD3), Ea2 (HD2), Eb1 (HD4), and Ecl (HD)) has been described earlier (Beug et al. 1982b). Further details of the origin of various erythroblast populations derived during the establishment of these lines are described in the text. The origin of the cell line Mal (HD11) from a pool of MC29 (RAV-2)-transformed macrophage clones (Graf 1973) has been described (Beug et al. 1979; Leutz et al. 1984).

Fibroblasts, macrophages, and erythroblast cell lines were cultivated in standard growth medium, a modification of Dulbecco's modified Eagle medium (Graf 1973) supplemented with $8 \%$ fetal bovine serum, $2 \%$ chicken serum, and $25 \mathrm{~mm}$ HEPES $\mathrm{pH}$ 7.3). Erythroblast clones were grown in CFU-E medium (Radke et al. 1982) lacking anemic serum.

\section{Isolation of the cell line Fa1}

TaSp7 fibroblasts were passaged at $42^{\circ} \mathrm{C}$ (Beug and Graf 1977) until they were senescent. They were then seeded in three tissue culture flasks $(250 \mathrm{ml})$ in $15 \mathrm{ml}$ of standard growth medium and subjected to partial medium changes every second to third day. After $\sim 8$ weeks, small islands of small, healthy looking cells appeared in two of the three flasks /two islands in one flask and one in the second). During the next 4 weeks, these islands grew slowly, but only one could be propagated further; the other two underwent senescence after passage. This cell population 
was subjected to cloning after passage for an additional 4 weeks, and the clones were screened for a temperature-sensitive phenotype. However, the clone initially selected (L3) became rapidly heterogenous and was therefore subjected to a second subcloning and screen for a bona fide temperature-sensitive phenotype. The cloned line that was finally selected (TaSp7 L3/17) displayed a fairly stable phenotype provided it was cultivated at $42^{\circ} \mathrm{C}$ for limited time periods $(<2$ weeks)

\section{Transformation parameters}

Analysis of fibroblast transformation parameters was done as described in Beug et al. (1978).

\section{Erythroblast differentiation assay}

Cells of the clone Ea and the cell line Eal were seeded in $\mathrm{pH} 8$ medium (Zenke et al. 1988) supplemented with 3\% high-titer anemic serum, insulin $(1 \mu \mathrm{g} / \mathrm{ml})$, and $15 \mu \mathrm{M}(\mathrm{Ea})$ or $25 \mu \mathrm{M}$ of the protein kinase inhibitor $\mathrm{H} 7$ (Glineur et al. 1990) and incubated at $42^{\circ} \mathrm{C}$ for 3-4 days (Ea) or 4-5 days (Eal). Controls were kept at $37^{\circ} \mathrm{C}$ in the same medium lacking anemic serum. Cells were then cytocentrifuged onto slides, stained with histological dyes plus neutral benzidine, and photographed under blue light to reveal histochemical staining for hemoglobin, as described in Beug et al. (1982a).

\section{Northern blot analysis}

Cells $\left(1 \times 10^{7}\right.$ to $2 \times 10^{7}$ in the case of fibroblasts and macrophages; $2 \times 10^{7}$ to $2 \times 10^{8}$ in the case of erythroblasts $\mid$ were lysed in guanidinium-rhodanide $14 \mathrm{M}$ GITC, $25 \mathrm{~mm}$ sodiumcitrate at $\mathrm{pH} 7.0,0.5 \%$ sarcosyl, $0.1 \mathrm{M} 2$-mercaptoethanol) according to Chomczynski and Sacchi (1987). Total RNA (10 $\mu \mathrm{g}$ ) was then separated on formaldehyde-agarose gels, blotted to GeneScreen membranes, and hybridized to the following probes: $p \beta A 13$, which contains a HindIII fragment of the chicken $\beta$-actin cDNA clone (Kost et al. 1983); pGdp53, which corresponds to the predicted coding sequence of chicken p53 cloned in pKCR3 (Soussi et al. 1988); and pGdRb2, which contains the central 1.6-kb EcoRI fragment of the cDNA for chicken $\mathrm{Rb}$. The $\mathrm{Rb}$ clone was isolated from a library of chicken embryo cDNA cloned in $\lambda g t l 1$ (Sap et al. 1986). The 1.6-kb fragment is flanked at the $5^{\prime}$ side by a $0.9-\mathrm{kb}$ EcoRI fragment and at the $3^{\prime}$ side by a $2.0-\mathrm{kb}$ fragment. These three fragments encompass the $\mathrm{Rb}$ open reading frame $(\mathrm{E}$. Ulrich, unpubl.). Hybridization was at $65^{\circ} \mathrm{C}$ according to Church and Gilbert (1984), and filters were washed twice in $2 \times$ SSC and once in $0.1 \times$ SSC at $65^{\circ} \mathrm{C}$. Blots were exposed on Kodak XAR 5 film for 1-7 days

\section{Isolation of wild-type and mutant p53 by PCR}

Primers were initially designed to amplify conserved regions II-V on a single fragment of $614 \mathrm{bp}$ on the basis of the sequence of Soussi et al. (1988). The sequences of the primers that were complimentary to p53 were GACTTCGACTTCCGGGTGGGGTTCGTGGAGG and TAGCCACGCCCCCGGCCCCGCCCCTCTTGCG. Flanking sequences provided EcoRI adaptors for cloning. Total RNA (10 $\mu \mathrm{g})$ from clone Ea and line Ea2 was amplified using 1 -min denaturation at $94^{\circ} \mathrm{C}$ and then $2 \mathrm{~min}$ at $55^{\circ} \mathrm{C}$, followed by $3 \mathrm{~min}$ at $72^{\circ} \mathrm{C}$. The resulting fragment was isolated from an agarose gel and cloned in the EcoRI site of pUC19. Sequencing of the amplified fragment by the chain termination method (Tabor and Richardson 1987) revealed a point mutation in RNA from line Ea2. To corroborate this, primers flanking the putative mutation were constructed and additional PCR reactions were performed. The sequences of the primers that were complimentary to p53 were ACCACGAGCGCTGCGGGGGG and CCCTACTTGGCGGCGGGGTA. The resulting fragment of $242 \mathrm{bp}$ was either cloned and sequenced as described above or pooled PCR products were sequenced directly.

\section{Acknowledgments}

We are grateful to Björn Vennström for chicken genomic and cDNA libraries, Robert Weinberg for the human Rb cDNA, and Thierry Soussi for the chicken p53 cDNA. We also thank Francisco Antequera and Richard Meehan for helpful advice, Gotthold Schaffner and colleagues for oligonucleotide synthesis and DNA sequencing, and Hannes Tkadletz for photography.

The publication costs of this article were defrayed in part by payment of page charges. This article must therefore be hereby marked "advertisement" in accordance with 18 USC section 1734 solely to indicate this fact.

\section{References}

Antequera, F., J. Boyes, and A. Bird. 1990. High levels of de novo methylation and altered chromatin structure at $\mathrm{CpG}$ islands in cell lines. Cell 62: 503-514.

Beug, H. and T. Graf. 1977. Isolation of clonal strains of chicken embryo fibroblasts. Exp. Cell Res. 107: 417-428.

Beug, H., M. Claviez, B. Jockusch, and T. Graf. 1978. Differen tial expression of Rous sarcoma virus specific transformation parameters in enucleated cells. Cell 14: 843-857.

Beug, H., A. von Kirchbach, G. Döderlein, J.F. Conscience, and T. Graf. 1979. Chicken hematopoietic cells transformed by seven strains of defective avian leukemia viruses display three distinct phenotypes of differentiation. Cell 18: $375-$ 390.

Beug, H., S. Palmieri, C. Freudenstein, H. Zentgraf, and T. Graf. 1982a. Hormone-dependent terminal differentiation in vitro of chicken erythroleukemia cells transformed by $t s$ mutants of avian erythroblastosis virus. Cell 28: 907-919.

Beug, H., G. Döderlein, C. Freudenstein, and T. Graf. 1982b. Erythroblast cell lines transformed by temperature-sensitive mutants of avian erythroblastosis virus: A model system to study erythroid differentiation in vitro. I. Cell Physiol. (Suppl.) 1: 195-207.

Bischoff, J., P. Friedman, D. Marshak, C. Prives, and D. Beach. 1990. Human p53 is phosphorylated by p60-cdc2 and cyclin B-cdc2. Proc. Nat1. Acad. Sci. 87: 4766-4770.

Buchkovich, K., L. Duffy, and E. Harlow. 1989. The retinoblastoma protein is phosphorylated during specific phases of the cell cycle. Cell 58: 1097-1105.

Chomczynski, P. and N. Sacchi. 1987. Single-step method of RNA isolation by acid guanidinium thiocyanate-phenolchloroform extraction. Anal. Biochem. 162: 156-159.

Church, G. and W. Gilbert. 1984. Genomic sequencing. Proc. Natl. Acad. Sci. 81: 1991-1995.

Diller, L., J. Kassel, C. Nelson, M. Gryka, G. Litwak, M. Gebhardt, B. Bressac, M. Ozturk, S. Baker, B. Vogelstein, and S. Friend. 1990. p53 functions as a cell cycle control protein in osteosarcomas. Mol. Cell. Biol. 10: 5772-5781.

Eliyahu, D., A. Raz, P. Gruss, D. Givol, and M. Oren. 1984. Participation of p53 cellular tumour antigen in transforma- 
tion of normal embryonic cells. Nature 312: 646-649.

Ghosh, S., A.M. Gifford, L.R. Riviere, P. Tempst, G.P. Nolan, and D. Baltimore. 1990. Cloning of the p50 DNA binding subunit of NF-kB: Homology to rel and dorsal. Cell 62: 1019-1029.

Glineur, C., M. Zenke, H. Beug, and J. Ghysdael. 1990. Phosphorylation of the v-erbA protein is required for its function as an oncogene. Genes \& Dev. 4: 1663-1676.

Graf, T. 1973. Two types of target cells for transformation with avian myelocytomatosis virus. Virology 54: 398-413.

Graf, T., D. Fink, H. Beug, and B. Royer-Pokora. 1977. Oncornavirus-induced sarcoma formation obscured by rapid development of lethal leukemia. Cancer Res. 37: 59-63.

Graf, T., N. Ade, and H. Beug. 1978. Temperature-sensitive mutant of avian erythroblastosis virus suggests a block of differentiation as mechanism of leukaemogenesis. Nature 275: 496-501

Gregor, V., E. Passarge, W. Hopping, E. Messmer, and B. Horsthemke. 1989. Epigenetic changes may contribute to the formation and spontaneous regression of retinoblastomas. Hum. Genet. 83: 155-158.

Hayflick, L. 1965. The limited in vitro lifetime of human diploid cell strains. Exp. Cell Res. 37: 614-636.

Hinds, P., C. Finlay, and A. Levine. 1989. Mutation is required to activate the p 53 gene for cooperation with the ras oncogene and transformation. J. Virol. 63: 739-746.

Huang, H., J. Yee, I. Shes, P. Chen, R. Bookstein, T. Friedmann, E. Lee, and W. Lee. 1988. Suppression of the neoplastic phenotype by replacement of the $\mathrm{Rb}$ gene in human cancer cells. Science 242: 1563-1566.

Jenkins, J., K. Rudgc, and G. Currie. 1984. Cellular immortalization by a cDNA clone encoding the transformation-associated phosphoprotein p53. Nature 312: 651-654.

Jones, P., M. Wolowicz. W. Rideout, F. Gonzales, S. Tapscott, and M. Harrington. 1990. De novo methylation of the MyoD1 CpG island during the establishment of immortal cell lines. Proc. Nat1. Acad. Sci. 87: 6117-6121.

Kost, T., N. Theodorakis, and S. Hughes. 1983. The nucleotide sequence of the chick cytoplasmic $\beta$-actin gene. Nucleic Acids Res. 11: 8287-8301.

Laiho, M., J. DeCaprio, J. Ludlow, D. Livingston, and I. Massague. 1990. Growth inhibition by TGF-beta linked to suppression of retinoblastoma protein phosphorylation. Cell 62: $175-185$.

Lane, D. and L. Crawford. 1979. T-antigen is bound to host protein in SV40-transformed cells. Nature 278: 261-263.

Levine, A., J. Momand, and C. Finlay. 1991. The p53 tumour suppressor gene. Nature 351: 453-456.

Lewis, R.B., J. McClure, B. Rub, D.W. Niesel, R.F. Garry, I.D. Hoelzer, K. Nazerian, and H.R. Bose. 1981. Avian reticuloendotheliosis virus: Identification of the hematopoietic target cell for transformation. Cell 25: 421-431.

Leutz, A., H. Beug, and T. Graf. 1984. Purification and characterization of CMGF, a novel chicken myelomonocytic growth factor. $E M B O$ /. 3: 3191-3197.

Linzer, D. and A. Levine. 1979. Characterization of a $54 \mathrm{~K}$ dalton cellular SV40 tumor antigen present in SV40 transformed cells and uninfected embryonal carcinoma cells. Cell 17: 43-52.

Ludlow, J., J. DeCaprio, C. Huang, W. Lee, E. Paucha, and D. Livingston. 1989. SV40 large T antigen binds preferentially to an underphosphorylated member of the retinoblastoma susceptibility gene product family. Cell 56: 57-65.

Macieira-Coelho, A. 1976. Metabolism of cells in culture. Gerontology 22: 3-8.

1980. Implications of the reorganization of the cell ge- nome for ageing or immortalization of dividing cells in vitro. Gerontology 26: 276-282.

Mercer, W., M. Shields, M. Amin, G. Sauve, E. Appella, J. Romano, and S. Ullrich. 1990. Negative growth regulation in a glioblastoma tumor cell line that conditionally expresses human wild-type p53. Proc. Nat1. Acad. Sci. 87: 6166-6170.

Metz, T. and T. Graf. 1991. v-myb and v-ets transform chicken erythroid cells and cooperate both in trans and in cis to induce distinct differentiation phenotypes. Genes \& Dev. 5: $369-380$.

Mihara, K., X. Cao, A. Yen, S. Chandler, B. Driscoll, A. Murphree, A. T'Ang, and Y. Fung. 1989. Cell cycle-dependent regulation of phosphorylation of the human retinoblastoma gene product. Science 246: 1300-1303.

Morrison, L.E., G. Boehmelt, H. Beug, and P.J. Enrietto. 1991. Expression of v-rel in a replication competent virus: Transformation and biochemical characterization. Oncogene 6: $1657-1666$.

Mulligan, L., G. Maltlashewski, H. Scrable, and W. Cavenee. 1990. Mechanisms of p53 loss in human sarcomas. Proc. Natl. Acad. Sci. 87: 5863-5867.

Munroe, D., J. Peacock, and S. Benchimol. 1990. Inactivation of the cellular p53 gene is a common feature of friend virus induced erythroleukemia: Relationship of inactivation to dominant transforming alleles. Mol. Cell. Biol. 10: 33073313.

Nigro, N., S. Baker, A. Preisinger, J. Jessup, R. Hostetter, K. Cleary, S. Bigner, N. Davidson, S. Baylin, P. Devilee, T. Glover, F. Collins, A. Weston, R. Modali, C. Harris, and B. Vogelstein. 1989. Mutations in the p53 gene occur in diverse human tumour types. Nature 342: 705-708.

Radke, K., H. Beug, S. Kornfeld, and T. Graf. 1982. Transformation of both erythroid and myeloid cells by E26, an avian leukemia virus that contains the gene. Cell 31: 643-653.

Rovinski, B. and S. Benchimol. 1988. Immortalization of rat embryo fibroblasts by the cellular p53 oncogene. Oncogene 2: $445-452$.

Sakai, T., J. Toguchida, N. Ohtani, D.W. Yandell, J.M. Rapaport, and P. Dryja. 1991. Allele-specific hypermethylation of the retinoblastoma tumor suppressor gene. Am. I. Human Genet. 48: 880-888.

Sap, J., A. Munoz, K. Damm, Y. Goldberg, I. Ghysdael, A. Leutz, H. Beug, and B. Vennstrom. 1986. The c-erb-A protein is a high-affinity receptor for thyroid hormone. Nature 324: 635-640.

Scheffner, M., B. Werness, J. Huibregtse, A. Levine, and P. Howley. 1990. The E6 oncoprotein encoded by human papillomavirus types 16 and 18 promotes the degradation of $\mathrm{p} 53$. Cell 63: 1129-1136.

Soussi, T., A. Begue, M. Kress, D. Stehelin, and P. May. 1988. Nucleotide sequence of a cDNA encoding the chicken p53 nuclear oncoprotein. Nucleic Acids Res. 16: 11383-11383.

Soussi, T., C. de Fromentel, and P. May. 1990. Structural aspects of the p53 protein in relation to gene evolution. Oncogene 5: 945-952.

Strauss, M., S. Hering, L. Lubbe, and B.E. Griffin. 1990. Immortalization and transformation of human flbroblasts by regulated expression of polyoma virus $\mathrm{T}$ antigens. Oncogene 5: $1223-1229$.

Takahashi, T., M. Nau, I. Chiba, M. Birrer, R. Rosenberg, M. Vinocour, M. Lecitt, H. Pass, A. Gazdar, and J. Minna. 1989. p53: A frequent target for genetic abnormalities in lung cancer. Science 246: 491-494.

Tabor, S. and C. Richardson. 1987. DNA sequence analysis with a modified bacteriophage T7 DNA polymerase. Proc. Natl. Acad. Sci. 84: 4767-4771. 
Wilcock, D. and D. Lane. 1991. Localization of p53, retinoblastoma and host replication proteins at sites of viral replication in herpes-infected cells. Nature 349: 429-431.

Wright, W.E., O. Rereia-Smith, and J. Shay. 1989. Reversible cellular senescence: Implications for immortalization of normal human diploid fibroblasts. Mol. Cell Biol. 9: 30883092.

Zenke, M., P. Kahn, C. Disela, B. Vennström, A. Leutz, K. Keegan, M. Hayman, H.R. Choi, N. Yew, J.D. Engel, and H. Beug. 1988. V-erbA specifically suppresses transcription of the avian erythrocyte anion transporter gene. Cell 52: 107119. 


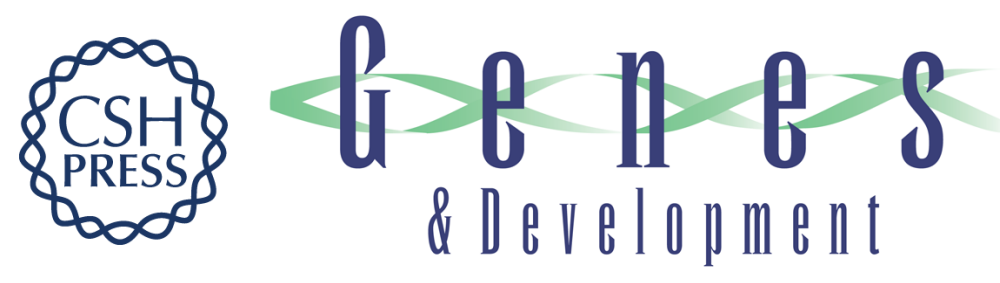

\section{Immortalization of conditionally transformed chicken cells: loss of normal p53 expression is an early step that is independent of cell transformation.}

E Ulrich, G Boehmelt, A Bird, et al.

Genes Dev. 1992, 6:

Access the most recent version at doi:10.1101/gad.6.5.876

References This article cites 53 articles, 16 of which can be accessed free at: http://genesdev.cshlp.org/content/6/5/876.full.html\#ref-list-1

License

Email Alerting Service

Receive free email alerts when new articles cite this article - sign up in the box at the top right corner of the article or click here.

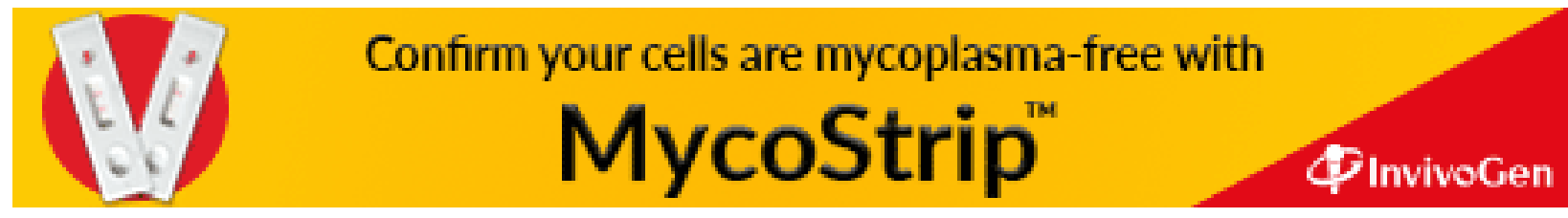

